\title{
Conditions, Standards and Practices of Inclusion for Children with Disabilities in Italian Infant School
}

\section{Lucia Chiappetta Cajola}

Università degli Studi Roma Tre - Department of Education (Italy)

doi: 10.7358/ecps-2015-012-chia

lucia.chiappettacajola@uniroma3.it

\section{MODALITÀ, STANDARD E PRATICHE DI INCLUSIONE PER I BAMBINI CON DISABILITÀ \\ NELLA SCUOLA DELL'INFANZIA ITALIANA}

\begin{abstract}
The highly integrative choice that Italy has decided to make for many decades is much appreciated at international level. It is an irreversible choice that requires continual improvements to be made in the school context which includes a great variety of individuals. During childhood, in fact, Italian school embraces, promotes and enriches the experience of every child from a developmental perspective; the educational activities offer opportunities for growth within a context oriented towards well-being, awareness and gradual development of the competences expected at different ages, between three and six years old. In such educational activities, the school is coherent with the principles of the inclusion of the person, considering the acceptance of diversity and active participation in each of the fundamental values. This paper regards the perspective of inclusion of children with disabilities in Italian infant school. It describes, both quantitatively and qualitatively, the situation, according to a framework of fundamental principles sanctioned internationally, based on the Italian Constitution, current laws, documents, informations and data from authoritative sources. The research, presented by the author in the "Deutschen Gesellschaft für Erziehungswissenschaft Kongress" (Humboldt Universität, Berlin, 9-12 March 2014), arose from a designed European comparative study from four selected member countries of the EU: Italy, England, Germany and Slovenia. The study aims to explain how inclusive education of children with disabilities in european school has developed, and how, currently, is arranged in connection with the school system's resources, the teachers training and the social expectations on the kindergarden.
\end{abstract}


Keywords: Disability, Full inclusion, Italian infant school, Support, Teachers training.

\section{INTRODUCTION}

This study arose from a qualitatively designed European study comparing four selected member countries of the EU: Italy, England, Germany and Slovenia ${ }^{1}$. It describes the situation concerning the inclusion of children with disabilities at infant schools in Italy, both quantitatively and qualitatively, according to a framework of fundamental internationally sanctioned principles, based on the Italian Constitution, current laws, documents, information and data from authoritative sources, which are listed in the following section. Some of the above principles will be referred to specifically in these pages while others will only be mentioned, depending on the socio-pedagogical and historical-cultural implications discussed. However, the main point of reference is the Constitution of the Italian Republic which, although it does not explicitly consider the position of disabled people, supplies them with adequate constitutional protection in its social justice programme, which supports the weaker members of society (Santosuosso, 1993; Onida, 2006 and 2009). This programme, in fact, through non-discriminatory legislation, offers support and emancipation, aiming towards effective social inclusion and the direct participation of the disabled in active life, especially at school and in the workplace. To be specific, our Constitution provides «recognition» and a "guarantee» (Article 2 of the Constitution) of the rights of the disabled, so that they obtain "equal social dignity" (Article 3 of the Constitution) allowing «full development of the human person» (Article 3, comma 2 of the Constitution). This is the solid base of the expansive parameter offered by the Constitution, fostering complete human development. Therefore, rights to a reduction in inequality for disabled people, in this case children, due to their natural diversity (Cancrini, 1974), are recognised. This is essential for the realisation of their right to equal opportunities, also pursuant to those «binding rights to political, economic and social solidarity» to which Article 2 of the Constitution requests peremptory compliance. In such a constitutional dimension, it is appropriate to underline that the history of the Italian

1 This research was presented by the author at the Deutschen Gesellschaft für Erziehungswissenschaft Kongress (Humboldt Universität, Berlin, 9-12 March 2014), https://www. dgfe2014.de/wpcontent/uploads/DGfE_Programm2014_K29web.pdf. In this context, data have been updated to the more recent Italian surveys. 
school, characterised by a pedagogical and anthropological approach focussing on the learner at the centre (Callari Galli, 1973), gives infant schooling a predominant role, considering the importance that this period of life assumes in the lives of every boy and girl (Montessori, 1938; Frabboni, 1975; Neri, 1980; Pontecorvo, 1990; Bertolini, 1992; Macchietti, 2005).

Therefore, school is coherent with the principles of including the person, accepting diversity, and actively participating in each of the fundamental values. Italy was among the first countries in the world to have thrown down the gauntlet for integrating pupils with disabilities (Canevaro, 2007; Pavone, 2010), a practice which was gradually extended to all school levels. Evidence will be given in the following pages of the particular care offered to disabled children in infant schools through appropriate organisational and didactic strategies, considered during the normal planning of the training offered (Chiappetta Cajola, 2012a and 2012b).

\section{INFANT SCHOOL AS CONTEXT OF GROWING, LEARNING, RELATIOSHIP AND LIFE}

Law no. 444 (18th March 1968) established infant schools (kindergarden) in Italy, but not as compulsory schooling ${ }^{2}$. The following year, Presidential Decree no. 647 (10th September 1969) Orientation of educational activity was issued. This proposed «the aims of education, development and preparation for attendance at compulsory school, integrating the involvement of the family». Nursery schools seemed to assume their own importance depending on the needs of the other educational agencies. This perspective was modified in the new Orientation of scholastic activity in state nursery schools. On 3rd June 1991, a Ministerial Decree proposed a school intended to respond prevalently to the growth needs of a child placed at the centre of didactic interest in a pluralistic and multi-ethnic society. However, it is not to be forgotten that since 1991 schools have had to deal with some innovations ${ }^{3}$ which have modified a strengthened scenario leading to the development of new programme documents. These were intended to make explicit «the basic levels of performance which all infant schools in the national instruction

2 Attendance at infant school became, in fact, an opportunity conditioned by the availability of resources and structures.

3 The main innovation was to set up "comprehensive institutes» (1994) which established new forms of vertical integration, favouring professional exchanges between infant school teachers, primary school teachers and teachers of first grade secondary school. 
system must guarantee as far as personal, social and civil rights to education and training are concerned ${ }^{4}$. To be specific, in the mid 90 s, the opportunity to further consolidate infant schools and their educational "programmes» under an institutional profile was considered. In this context, a wide-ranging debate developed during which it was hypothesised that children should start compulsory schooling a year earlier, that is from 5 years old. However, the proposal was set aside in favour of a "generalisation and qualification" of the education system. In this social, political and cultural climate, a process for redefining school organisation started, the legislative summary of which can be found in Law no. 53/2003. This includes infant school, and the revision of Legislative Decree no. 59 (19th February 2004), generating the National Recommendations for personalised study plans for educational activity, which substituted the Guidance document of 1991. One of the major criticisms of the Recommendations concerned the way in which they were rapidly imposed on the schools (infant, primary and the first grade of secondary), with no experimental phase or sharing of pedagogical choices. This weakened its structural installation and the introduction of the so-called "personalised plan» was put into question. This was interpreted as a means of underlining the sense of devaluation of the differences between pupils, based only on their initial conditions, and to impoverish the social building of knowledge ${ }^{5}$. Therefore, this was considered an opportunity to put aside the text on National Recommendations 2004 and to once again assert the sense of infant school as a motivating environment, affective in life, relationships and learning. With the National Recommendations for the curriculum of infant school and the first cycle of education, issued in September 2007, there was a return to the idea of a curriculum (Baldacci, 2006) as an efficient means to raise the quality of the school and help children to become citizens of tomorrow. This would combine the needs and rights of an individual learner within the distinctive features of a learning group, exalting the values of cooperation and solidarity. Therefore, it could better focus on the fact that school is immersed in a much wider context of cultural stimulation. However, scholastic learning is only one of the many formative experiences

4 The new programme document was passed in Legislative Decree no. 59, Appendix A (19th March 2004), entitled National recommendations for personalised plans in educational activities.

5 It became possible for families to enrol their children several months in advance (that is, those born by 30th April of the school year in question, rather than 30th December or, if requested, by the 31 st January). This institutional and cultural operation brought about the drawing up of Recommendations for infant school 2004, which did not bring about any substantial change, neither on a cultural nor an organisational level, so much so that within the scholastic panorama of infancy, the document passed almost unobserved. 
that children have (Trisciuzzi \& Cambi, 1989). In this context, the school has the great responsibility of concentrating on being a space where one can learn and manoeuvre in a more and more complex world, where the borders between natural and artificial seem to disappear, and where the problems of one's own environment are confused with those of the entire planet. This entails, on one hand, not neglecting the potential for developing the abilities (Vygotskij, 1974; Dixon-Krauss, 2000) and talents of each child in any way and, on the other, the great fragility derived from social models which are not always easy to accept. The Recommendations of 2007 is an open pedagogicalcultural document which resulted from a testing process in which teachers were called on to verify the adequacy of its content. This verification even included the possibility of making modifications and/or inclusions before it became the "definitive text", and in infant school it was articulated according to different fields of experience. Other than this characteristic, the document does not decree learning objectives, but limits itself to envisaging only some "aims for the development of competence», a choice which leaves the teachers with the task of creating their own educational programmes. It is to be underlined, in general, that all the drafting of the document concerning infant school is characterised by a particularly concise text intended to highlight children from 3 to 6 years old in specific detail, rather than emphasise the continuity of the curriculum as far as first cycle of education. The 2007 text gathered a large following on the part of teachers and initiated a great deal of unanimous activity made up of exchanges of ideas, comments, and clarifications, with expert contributions from Ministry circles, as well as from representatives of the scientific community, trades unions, and professional and disciplinary associations. Contemporarily, the scholastic world was asked its opinion of a new rough draft by means of a questionnaire from which it was possible to positively orientate the work being carried out, rather than only acquire suggestions and proposals for modifications to the document. In November 2012, the approved rules ${ }^{6}$ for the new recommendations of the curriculum for infant school and the first cycle of instruction came to light and were put into action immediately. These rules confirmed the validity of the educational and cultural structure of the Italian school, with its vocation for welcoming and inclusion, which had been consolidated over so many

6 Regulations concerning national recommendations for infant school and the first cycle of instruction curriculum, according to Article 1 of Presidential Decree no. 89 (20th March 2009). As the recommendations fully came into effect in the school year 2013-2014, among which Ministerial Decree no. 254/2012, the administration, in its various sections, was, for many years, involved in giving adequate support to scholastic institutions through a combination of accompanying measures, consisting of offering information, training, research, monitoring and documentation (Ministerial Circular no. 22/2013). 
years. Similarly, the rules outlined the need to promote the acquisition of more solid competencies in our young and very young, aiming to re-evaluate the essentials: those which count in a child's development.

More important legislative references are bill no. 1260 Provisions for integrated education and education from birth to six years and the right of girls and boys to equal learning opportunities, Communication no. 66/2011 of the European Commission Early childhood education and care: Providing all our children with the best start for the world of tomorrow (Brussels, 17th February 2011), European Recommendation no. 112/2013 (20th February 2013) Investing in children for breaking the cycle of social disadvantage and the recent Italian Law no. 107/2015 The Good School: Reform of the national system of education and training.

\subsection{Inclusion in the Italian educational system: development and current issues}

The Italian school process of inclusion began in the 70's and has developed in five stages: exclusion, institutionalization, ordinary school placement, integration and full inclusion (Chiappetta Cajola, 1999). Nowadays the Italian situation seems to be very complicated because there is a great heterogeneity of pupils with special educational needs in every class (MIUR, 2012).

The current debate concerns, on the one hand, what «inclusion» means in different cultural frameworks (UNESCO, 2005; OECD, 2012; Medeghini et al., 2013), and on the other hand, the effectiveness of the Italian model.

According to Ianes (2014), the state of integration in Italy is very complex to be critically analyzed, it deeply interests the Italian school and it develops taking into consideration more fronts.

One of the main positions is the one of the radical neo-Marxist critics, who reports to the Italian Disability Studies. They aim to transform school profoundly and to contrast the idea of integration of students with disabilities. In fact, they consider the idea of integration as a product of the old model of assimilation-segregation and therefore a form of oppression. A second criticism arises from the associations of families of students with disabilities. They often face the lacks of education and management aspects through judicial appeals.

Ianes defines the third position as «critical conservative». It is the position of the main associations of people with disabilities and their relatives. Many professors of special education accords with this position. They recognize the difficulties of inclusion but they are skeptical about the possibility 
of a radical change. On account of this, they support the need of gradual improvement about how inclusion is currently realized.

The "critical structural evolution" is the fourth position. It requires the change of some structural issues considered to be priorities. Among the main weak points this critique highlights that the normal teaching is not enough inclusive, the support teachers presence is often ineffective, and there is a lack of cooperation between support teacher and other teachers (Chiappetta Cajola, 2007; Associazione Treellle et al., 2011).

Therefore, the current Italian debate does not question the value of inclusion but it encourages to increase the system's resources. It emphasizes the need to develop the culture and the realization of inclusion. In order to accomplish this, it is very important to improve teachers' skills to promote closer interaction between all members of the educational community.

\section{THE LEGAL PATH FOR FULL INCLUSION OF CHILDREN WITH DISABILITIES}

This section is intended to supply a brief legal digression referring specifically to the integration of children at infant school, outlining the measures which have been introduced and regulated nationally. Therefore, it is necessary to go back to the beginning of the 80 's to the cultural and social climate determined by Law no. 517/77 7 . Such a fundamental initiative represents not only, in general, a significant indication of an advanced society, but also, in the specific case of Italian civil jurisdiction, the objective of a precise constitutional programme. This occurred with the proclamation of Law no. 270 (20th May 1982) ${ }^{8}$, which extended the "post of support teachers» to state

7 Law no. 517/1977 Rules on the assessment of pupils and the abolition of examination resits as well as other modifying rules for the school system. Articles 2 (primary school) and 7 (first grade of secondary school) state that "the school activates forms of integration in favour of handicapped pupils». Previously, Law no. 118 (30th March 1971), Conversion into law of Legislative Decree no. 5 (30th January 1971), and new regulations in favour of the disabled, maimed and civil invalids, ordered (Article 28) that compulsory education must occur in the normal classes of public schools. In this sense, the law in question went beyond the standard of the special schools, which however, it did not abolish, by calling for the insertion of handicapped pupils into normal classes, but left this to the wishes of the families. To facilitate their inclusion, the law included transport and access to school buildings by overcoming architectural barriers for handicapped pupils, as well as help during school hours for the most serious cases.

8 Revising the regulations for recruiting teaching staff in nursery, elementary, secondary and artistic schools, restructuring their organisation, adopting suitable measures to avoid creating temporary employment and reassigning temporary staff to permanent posts.

ECPS Journal - 12/2015

http://www.ledonline.it/ECPS-Journal/ 
nursery schools: in other words, it assigned specialised teachers ${ }^{9}$ to sections ${ }^{10}$ attended by disabled children.

Almost ten years later, the Orientation of 1991 brought the subject of integrating disabled children at infant school to a prominent position by means of a very significant statement, which reads as follows,

The school accepts all children, even those with difficulties in adaptation and learning or with disadvantages which may be due to conditions of a sociocultural nature, and children with disabilities. To the latter, it offers adequate educational activities, effectively integrating them by means of an articulated educational and didactic plan, which is an integral part of the programme. This plan requires an accurate «functional diagnosis» which makes it possible to identify possible deficits and potential abilities, and fosters conditions which can reduce the situation of handicap through an analysis of the organisational, cultural and professional resources of the school, recognition of the living conditions and educational resources of the family, and the location of existing opportunities in the area. When formulating specific individual educational projects, the subject must be considered protagonist of his own personal growth process. He must be guaranteed periodical and appropriate tests and the collaboration of specialist services concerned with the connection between therapeutic treatment and school activities, based on appropriate inter-institutional understanding. [...] All the school teachers, and not only the support teachers, contribute collectively towards the success of the general educational project and integration and a significant proportion of non-teaching and auxiliary staff also take part. Detailed care is taken in identifying teaching-learning situations, empowering contexts of communication and extending relational opportunities. The timeliness of educational activities for integration are one of the most effective ways to prevent hardship and the lack of success which can still be found along a school career. (Orientation 1991, p. 11)

Following the timeline, another very important document which also had a concrete impact on infant schools was Guidelines for the scholastic integration of pupils with disabilities, which the Ministry of Education, Universities and Research (MIUR) published for schools at all levels in order to supply a series of directives. While these respected school autonomy and current laws, as is clear from the premise of the text, they also aimed to improve the integration process of disabled pupils. The Guidelines are not re-traceable references specific to infant school, ad hoc. However, they can be referred to consider-

9 The role of «support» teacher was created by Presidential Decree no. 970/1975, as a «specialised» teacher, different from all the other curriculum teachers, further defined by Law no. $517 / 77$.

10 "Class» is the word used both in compulsory schooling and higher education, whereas «section» is used to refer to the infant school. 
ing the fact that they outline the «inclusive school» substantially, taking the WHO ICF model, its components and related responsibilities as a reference, and also include ample references to the most important international pronouncements on the subject.

Infant school is explicitly referred to when underlining the importance of the moment when the pupil passes from one grade of education to another and of "the disabled pupil's individual file, which must be supplied before leaving infant school, or at least at the beginning of a scholastic course, in order to document the developmental path travelled on the scholastic journey» (Part III).

Finally, the perspective of the National Recommendations of 2012 proposes, «The school fully realises its own public function by working towards the scholastic success of all students, with particular attention to the support of various forms of diversity, disability or disadvantage" (National Recommendations for the curriculum, culture, school and person 2012, p. 9).

\section{AIMS AND ENROLMENT CRITERIA}

Infant school (whether state, recognised, private or funded by the municipality), is available to all children between three and six years old and responds to their rights to education and care, in line with the principles of the cultural and institutional pluralism in the Constitution of the Republic, in the Convention on the rights of infancy and adolescence and in European Community documents. It sets the objective of promoting the development of identity, autonomy and competencies in children and guides them to become citizens through organising their life environment, relationships, and quality learning. This is guaranteed by the professionalism of the staff and by social and educational dialogue with families and the community.

Infant school, in fact, is represented as a protective environment, accepting diversity and promoting the potential of every child. It recognises this plurality of elements which creates so many possibilities for both cognitive and emotive growth, making the potential of each and every child evolve, promoting their trust and willingness, and accompanying them in the adventure towards knowledge. The school promotes well-being and serene learning through attention to its surroundings, educational spaces, and careful guidance over an entire school day ( 8 hours a day, 40 hours a week). As is customary, the ministerial circular relating to enrolments every year contains a reminder that allows families, if they wish, to take advantage of a reduced timetable with attendance only in the mornings. At the moment, this choice 
has been taken up by less than $9 \%$ of families. This means that great care has been taken in organising conditions in infant school so that they respond to the criteria of quality and the skilled treatment of all the children.

Bearing this in mind, it is necessary to be aware both of the risks connected to the strong presence of the private sector (about 30\%), which often escapes the austere logic of inspections and assessments (notwithstanding the Parity Law 2000), and the difficulties in which the state school flounders, with a high number of children, not always efficient pedagogical coordination, and limited resources for consumable materials and teaching equipment. These are problems to be tackled at the roots, also in order to strengthen the consensus for enriching experimentation in new services for infancy, for their decisive standardisation and qualification. As far as the sections which accept disabled children are concerned, there is a tendency to limit the number of enrolments, bringing them usually up to 20, as envisaged by Ministerial Decree no. 141/1999. In general, every section can accept a maximum of 25 children; only exceptionally, in the case of unaccepted requests by other nearby state schools, can the limit reach 28 children per section. This will also depend on the availability of staff and the current total of support teachers regionally, seeing that some regions, based on the number of disabled pupils enrolled, have, in proportion, more places than necessary. It is to be remembered that crowding in the sections also often depends on a lack of other services for infancy in the district. It is fundamental that disabled children have, according to Framework Legislation no. 104/1992, absolute precedence in the enrolments. To be able to profit from assistance at school, the family must ask their own local health authority for a medical certificate confirming the disability and present it at the school. The school, on the basis of the certificate presented, requests a support teacher who will be able to accompany and guide the disabled child in the section during didactic activities together with the other children. Children with disabilities have priority for access to childcare services. Enrolling for nursery and infant school is guaranteed on the basis of the current law and local agreements. In these educational establishments, disabled children are together with children without disabilities, according to the Italian model of «full inclusion». Generally, parents turn to nurseries and infant schools close to their homes or to their places of work; children with disabilities always have precedence over other children. All information regarding nurseries and infant schools run by the municipality is provided by the offices of the municipality of residence. Regional and provincial education offices provide information regarding state and officially recognised private schools. Information about certification is provided by the local health authority in the area of residence and from the educational establishments themselves. 


\section{KINDERGARTEN AND SOCIAL EXPECTATIONS}

Expectations concerning daily childcare services have stimulated not only a progressive increase in enrolments at kindergarten but also their attendance. Kindergarten, although not compulsory in the Italian school system, has acquired greater consideration from parents who increasingly decide to enroll their children. This is due to the importance that society has assigned to kindergarten over the years, supporting the change from its being considered welfare help for families to being a real and proper educational agency itself with well-defined objectives, qualified human resources, learning environments, adequate socialization, and teaching methodologies consistent with the fundamental principles of pedagogy and didactics as well as developmental and educational psychology. At the same time, a culture of childhood has been developing and it has been enriched by important recognition worldwide. On a national level, the Ministry of Education, local authorities and private agencies have acted together specifically for this purpose. The combination of these factors has resulted in social expectations: the hope to be able to count on a quality service by trained professionals, updated specifically and able to meet the needs of children with or without disabilities. These children, in fact, experience interaction in the same environment and gradually learn to recognize and respect diversity through their involvement in various projects (concerning psychomotricity, music, music therapy for integration, projects for the prevention of language disorders and psychomotor retardation, etc.). The confidence of parents has thus increased concerning early educational action in day care centres, taking place in a school-family continuity. As a result, they consider kindergarten as a structure working towards preventing difficulties, i.e. a basic service for all. They expect flexible organization (timetabling, feeding, etc.) corresponding to their specific needs and those of their children. Parents are informed about school training proposals and they also require meetings and systematic communication between the family and school. Therefore, the importance of acting in a context in which all participate is better understood.

\section{TOOLS FOR INCLUSION IN ITALIAN SCHOOLS}

Care of children with disabilities is achieved by the services that accommodate the plurality of children with and without disabilities. As far as Italian legislation is concerned, separate educational facilities are not, in fact, envisaged. Specific tools to promote the process of integration are those in 
Article 12 of Act no. 104/1992, i.e. the functional diagnosis, the dynamic functional profile and the individualized education plan, which are interdependent. The above Article supplies extended information for implementating the school education project. Subsequent Articles 13, 14, 15 and 16 (with Article 17 devoted to vocational training) are also dedicated to school and university courses. Integration between institutions, in particular, is highlighted by the Act, and coordination concerning the tasks attributed to the local health authorities (ASL) for the preparation of the functional diagnosis, the dynamic functional profile and the individualized educational plan are provided for by Act no. 104/1992. Teachers, parents, health care workers and specialists participate in the preparation of these last two tools. The relationships between the various agencies for integration are facilitated and mediated by Regional Support Centres (CTS) and Territorial Inclusion Centres (CTI), which depend on their regional education offices. In infant schools, the educational environment is considered the integrative background (Zanelli, 1986) in which elements that are far from one another connect; it is very useful to understand how mental processes (cognitive processes) are accomplished, and what symbology assists in storing and linking them (Canevaro, 1996). A child grows adequately if the school devotes care to "applied cognition", which allows him to learn to solve practical problems concerning play, feeding, personal hygiene, locomotion and verbal language. Only in this way he will then arrive at problems of a "symbolic cognitive» character: those organised more in his head than in the context. The background for integration is based on the concept of the educational context as a co-evolution of stories and, therefore, of different identities where each diversity represents a resource in a community-organization which, under a methodological profile, can be defined as action-research. It is therefore the connective structure of the infant school, allowing the interweaving of resources (support teacher, assistant to the person, educator) and the "construction of complementarity», which is necessary for all children, especially those with disabilities.

Even disabled children «in a grave situation» (as defined by Law no. 104/1992) attend ordinary schools with a support teacher and other specialised staff for educational assistance, provided by local authorities. The schooling of children in so-called "grave situations» is therefore a right and implies a project to be carried out by means of «specialised» support. To fulfil its own conclusive mission for all pupils (with or without disabilities), each infant school, as in all schools at successive levels, works out its own Annual Plan for Inclusion (PAI). The PAI is «a moment of reflection in the educational community to create a culture of inclusion, the background and the foundation on which to develop teaching, carefully adapted to the needs of 
each pupil to achieve common objectives» (MIUR, note of 22nd November 2013). The PAI is therefore a substantial part of the formative offer (POF) of each school and its intention is to "bring out weaknesses and strengths, reveal types of different special educational needs and the resources that could be used as well as all the difficulties and problems encountered, and make the school community aware of how substantial and varied the spectrum of critical issues within the school can be. This survey will be useful to guide the action of the administration in favour of schools with particularly complex and difficult situations» (MIUR, note of 22nd November 2013). To do this, each school has established a Working Group for Inclusion (GLI) which coordinates in the school, connecting all the specialised resources, including those of the Working Group for disability, as laid down in Article 12, paragraph 5 of Law no. 104/1992.

\subsection{Specialised schools for children with severe psycho-physical and sensory disabilities}

Only in very few places of the nation, there are specialised centres and institutes, semi-residential and residential, which welcome only children with severe multiple disabilities, i.e. children who can be, for example, deaf, blind, with Down syndrome or with severe motor disabilities. In these facilities, professionals who interact with children and with each other, have highly specialised skills, which are systematically updated: teaching, health, psycho-social staff, etc. The daily routine is punctuated by rehabilitation activities and medical and educational care, bearing the person and his integral development in mind. One example is the Leonarda Vaccari of Rome, a centre for re-educating, rehabilitating and integrating people with mental and physical disabilities, from childhood to adulthood. The institute works towards the physical and psychological rehabilitation and the social and educational integration of children from 3 to 6 years old. The centre supplies the clinical care needed as well as diverse rehabilitation therapies. The institute also promotes and carries out research ventures of scientific interest, study and documentation in the field of psycho-physical disabilities as well as integrated teaching. These activities may also be in collaboration with the authorities and public and private institutions with similar purposes, or otherwise connected to them. Another example is the Bignamini Special State School. This is part of the Istituto Comprensivo Falconara Center (Ancona) which is housed within the Don Gnocchi rehabilitation centre, thanks to an agreement between the Administrative Services Centre and the Foundation. Under this agreement, the Institute offers the school premises, furnishings, 
auxiliary staff, a canteen service and transportation, as well as the psychomedical and pedagogical rehabilitation team. It mainly hosts children who have multiple disabilities and severe psycho-physical and sensory disabilities, often accompanied by a lack of physical control such as: infantile cerebral palsy, West syndrome, akinetic tetraparesis, encephalopathy transmissible from microcephaly, relational behavioural disorders. Every child, in addition to having his own programme and his individualized activities, also needs constant monitoring because their conditions are often followed by complications, such as respiratory distress, epileptic seizures and repetitive behaviour. Therefore, the location of the school within the Institute is especially beneficial because, in case of necessity, assistance can be obtained from the medical team.

\section{ITALIAN SCHOOL INCLUSION: STATISTICAL DATA}

In the inclusive Italian system, care of children with disabilities from 3 to 6 years old, in both state and non-state infant schools across the nation, continues across successive school levels. The following tables and pie charts show the number of infant schools and educational institutions, both state and officially-recognised private schools, the number of students with and without disabilities enrolled at different school levels in different Italian regions, and the number of support teachers in the various regions. Here, the intention is to underline in detail how, starting from nursery and infant school, the child with disabilities has a full guarantee of integration, thereby assuring his right to education and training «in infant school and in the ordinary classes of educational institutions of all types and at all levels as well as university» (Law no. 104/1992, Article 12). The process of integration implies recognition of the importance of infant school, and its attendance, considered as completely normal in the history of the growth of each child (Table 1 and Figures 1-3).

Figure 4 shows the number of teachers for support activities in infant schools and at all subsequent educational levels, divided according to region. Note that in particularly complex situations arising from «severe» disabilities, the Ministry of Education, Universities and Research may allow a specialised teacher to perform support activities only in the section that contains a child in a situation of particular complexity. The teacher's working hours are carried out entirely in that section. In situations of non-severe or complex disabilities, the support teacher can work in multiple sections attended by children with disabilities. 


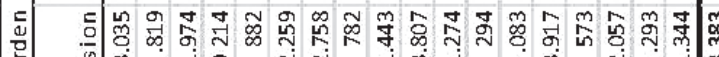

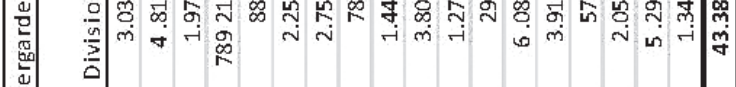




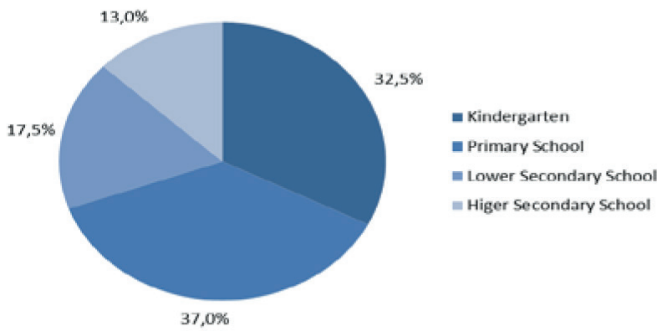

Figure 2. - Schools and school levels - 2014/2015.

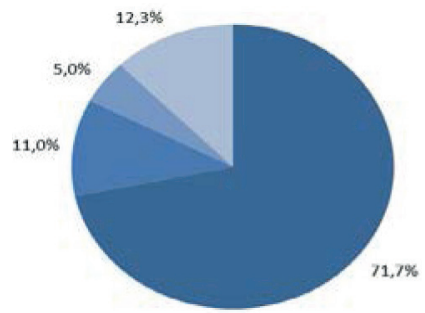

= Kindergarten

- Primary school

m Lower Secondary school

a Higer Secondary School

Figure 3. - Schools and school levels - Private school (Law of parity) - 2014/2015.

\begin{tabular}{|l|r|r|r|r|r|}
\hline Region & Kindergarden & Primary School & Lower Secondary School & Higher Sccondary School & Total \\
\hline Piemonte & 585 & 2.364 & 1.981 & 1.780 & 6.710 \\
\hline Lombardia & 1.050 & 6.016 & 4.124 & 1.939 & 13.129 \\
\hline Veneto & 493 & 2.927 & 2.224 & 1.468 & 7.112 \\
\hline Friuli & 141 & 452 & 377 & 265 & 1.235 \\
\hline Liguria & 175 & 917 & 664 & 562 & 2.318 \\
\hline Emilia Romagna & 443 & 2.446 & 1.637 & 1.777 & 6.303 \\
\hline Toscana & 450 & 1.638 & 1.225 & 1.147 & 4.460 \\
\hline Umbria & 118 & 537 & 380 & 375 & 1.410 \\
\hline Marche & 299 & 959 & 681 & 840 & 2.779 \\
\hline Lazio & 1.225 & 5.226 & 3.273 & 2.812 & 12.536 \\
\hline Abruzzo & 276 & 870 & 719 & 696 & 2.561 \\
\hline Molise & 87 & 262 & 184 & 240 & 773 \\
\hline Campania & 1.191 & 4.820 & 4.123 & 3.459 & 13.593 \\
\hline Puglia & 801 & 2.794 & 2.212 & 2.700 & 830 \\
\hline Basilicata & 86 & 330 & 268 & 1.507 \\
\hline Calabria & 356 & 1.553 & 1.002 & 1.068 & 3.979 \\
\hline Sicilia & 983 & 3.925 & 3.167 & 796 & 10.057 \\
\hline Sardegna & 297 & 998 & 824 & 4.236 & 101.391 \\
\hline Italia & 9.056 & 39.034 & 29.065 & 2915 \\
\hline
\end{tabular}

The projected and expected value for the support posts (at the date of this focus is 101.391) amounted to 103.000 .

Source: MIUR, General Directorate for Studies, Statistics and Informative Systems - Statistic Service - Table 3: Support teacher places for Region and school level - Public School - 2013/2014.

Figure 4 . 


\section{The TRAINING OF SUBJECT TEACHERS TO ENCOURAGE THE INCLUSION PROCESS}

For some time, there has been the conviction that curricular teachers, at all levels of the school, should have good basic training in the subject of Special Pedagogy and Special Didactics in order to efficiently promote the integration process (UNESCO, 2008). Other than the work carried out by specialised teachers, all teachers should, in fact, be able to carry out a collective course in a class which has a disabled person. This specific aspect is undeniable, not only to strongly confirm what is contained in the current rules about the joint ownership and shared responsibility of a section or class in which the curricular and support teachers operate, but also to give concreteness to their project cooperation and management, and therefore to the decisions of both. Such a need responds to Ministerial Decree no. 249 (10th September 2010) Regulations concerning: The definition of the discipline of requisites and the method for initial training of teachers in infant, primary and secondary schools, first and second level, according to Article 2, comma 416 of Law no. 244 (24th December 2007) ${ }^{11}$. All the training courses include, in fact, the acquisition of linguistic competencies (English, level B2), competence with technological teaching aids, and didactic competencies aimed at favouring the scholastic integration of disabled pupils. To become teachers at infant and primary schools, Ministerial Decree no. 249/2010 set up a "Teaching degree course of one cycle for teaching in infant and primary school» (Article 6). The course, the structure of which is defined by the decree itself, has a limited number of students who have to pass an entrance test. It is run by the Faculties of Training Sciences and other faculties authorised by the Ministry of Education, Universities and Research. Activities of indirect and direct internships (the latter carried out in schools) start in the second year of the course. They last for a total of 600 hours, equal to 24 university training credits, and are organised so as to ensure a progressive increase in the number of related training credits up to the last year. In the initial phase of internship, the student is oriented towards a choice between infant and primary school. The universities make use of their own teaching personnel and school managers and the teaching degree courses make use of teacher coordinators (Article 11, comma 2) and tutor organisers (Article 11, comma 4). The teaching degree course concludes with a thesis and a final report concerning the internship which together, after having passed the exams, have the value of a teaching qualification in infant or primary school. To this end, the exam

11 The law of 24th December 2007, no. 244 Instructions for the creation of an annual and long-standing assessment of the state balance sheet (Financial Law 2008). 
commission, nominated by the appropriate academic authorities, includes two tutor teachers and a representative from the Regional Schools Office. As may seem obvious, in this decree, the rights of all students to have professionally qualified teachers are emphasised. Such a right represents a principle of professional ethics directly linked to the constitutionally sanctioned right to study, and it also transmits the message that the integration of the disabled child is the responsibility of every school and all teachers and it is not, as sometimes happens, to be delegated to support teachers. In this respect, MIUR has activated further training initiatives on the subjects of integrating disability and other diversities throughout the nation, offered preferably to curricular teachers at infant school and other school levels, in order to form closer collaboration with the support teacher, and therefore favour the inclusion process. To this end, various activities have been organised by universities all over the country, especially courses at high professional levels: Masters at first and second level, and specialised courses on the theme of scholastic integration.

\section{SPECIALISED TRAining TO BECOME AN INFANT SCHOOL SUPPORT TEACHER}

The regulations issued in Ministerial Decree no. 249/2010, mentioned above, also contain instructions concerning a «training course for specialising in didactic support activities with disabled pupils» (Article 13), to be followed only at university. These courses envisage the acquisition of a minimum of 60 training credits, including at least 300 hours internship (equal to twelve university training credits), to be clearly organised for infant, primary or first or second grade secondary school. The characteristics of the training course are defined in the university regulations (adapted for that purpose), conforming with the criteria of the Ministry of Education, Universities and Research, after consulting the National University Council and competent national associations. Teachers who have already obtained their teaching qualification can join these courses. However, there are a limited number of courses planned by MIUR, bearing in mind the needs of the national education system and presupposing a pass at the university entrance test. At the end of the course, the candidate who successfully passes the final examination obtains a specialist diploma in didactic support activity with disabled pupils. This specialisation permits registration on the lists of support teachers so that they may be employed temporarily or permanently in any of the positions available. Ministerial Decree, 30th September 2011, establishes «Crite- 
ria and Methods for organising training courses for the activity of support, according to Articles 5 and 13 of Decree no. 249» (10th September 2010). It establishes the profile of the specialised teacher in particular, as well as the content of the entrance test, teaching, workshop activities and teaching practice, university training credits and the organisational aspects of specialist courses for support teachers. These courses are reserved for teachers who already have a qualification to teach at the school level at which they wish to continue as support teachers, and who are included in the rankings of those admitted to the course. The entrance test is prepared by each university and is based on a preliminary test, one or more written and/or practical tests and an oral test. Before briefly supplying any information relating to the profile of the specialised teacher, teaching, workshop activities and internship (Appendix A of the Decree), it seems apt to share some thoughts on salient aspects of the Decree. First of all, the relevance of the decision to allow access to the specialisation course to those already in possession of a teaching qualification, seems, as a result, relevant to qualify the term «support» with the adjective «didactic». In this way, the principle introduced by Law 104/1992, according to which integration is carried out within a process guaranteed by an integrated support system of which didactic support is a part, is underlined. Moreover, the particular attention given to training initiatives offered by specific internships seems to be equally important. A related outline of the profile of the specialised teacher is presented in the following.

The specialised support teacher is assigned to the class in which a disabled pupil is enrolled; she assumes the joint ownership of the section and the class in which she works, participates in the educational and didactic programme for the children and the planning and assessment of the activities concerning interclass councils, class councils and teachers' meetings according to Article 13, comma 6 of Law no. 104 (5th February 1992). She deals with educative-didactic activities by means of support activities with the class, to ease and promote the process of the disabled pupils' integration. She offers her professionalism and competence to significantly contribute her support to the class with educational-didactic collective action according to the principles of co-responsibility and cooperation.

The specialised support teacher must therefore possess:

- theoretical and practical competencies in the field of special pedagogy and didactics;

- psycho-pedagogical knowledge of the types of disability;

- competencies in the field of pedagogy of the helping relationship;

- knowledge and competencies on modalities for interaction and the educational relationship with pupils in the class, promoting pro-social behaviour among them, and between them and the scholastic community; 
- educational competencies in family dynamics and ways to involve and cooperate with the families;

- in-depth knowledge of a theoretical and operational nature for an interdisciplinary approach to the study of body-mind interaction, psychomotor education, behaviour and human learning;

- in-depth knowledge of a theoretical and operational nature relating to communication processes;

- familiarity and competence with experimental, observational and simulation methodologies and practice in the field of education and special didactics;

- the ability to analyse and understand cognitive processes at both individual and collective level, whether in the disabled or not;

- the knowledge to co-devise, co-monitor and co-conduct innovative projects aimed at promoting the process of integration inside a particular class;

- special didactic competencies in anthropological, humanistic and scientific fields;

- didactic competencies in meta-cognitive and cooperative approaches;

- special didactic competencies in intellectual and sensory disabilities;

- psychoeducational competencies for handling relational and behavioural disorders;

- pedagogical-didactic competencies in the combined management of the class;

- competencies to monitor and evaluate educational and developmental action;

- knowledge of the regulatory-legal field on school integration and human rights;

- didactic competencies with information technology and communication (ICT);

- competencies in communication and collaboration with colleagues and workers in the social and health services;

- pedagogical-didactic competencies to carry out the most efficient and efficacious ways to individualise and personalise an educational path;

- pedagogical competencies to develop an individualised educational project for the "Life Plan»;

- didactic competencies aimed to develop communicative and linguistic abilities;

- observation and assessment competencies regarding the various aspects of human functioning according to the WHO's ICF approach.

Teaching, for all school levels, is related to the following subject areas: Didactics and Special Pedagogy, Psychology of Development and Psychology of Education, Public Law, and Infantile Neuropsychiatry. The workshops are 
diversified for each grade of school; the activities are carried out by favouring a cooperative and collaborative teaching methodology: research-action, meta-cognitive learning through work groups, simulations, in-depth analyses, experience applicable to real or simulated situations, applicable experience related to training activities in the subject areas typical of the class (class management). The following subject areas are planned for teachers at infant school: Didactics of Education, Special Didactics: Communicative Codes in Linguistic Education, Special Didactics: Codes of Linguistic and Mathematical Logic, Didactics in the Anthropological Field, Didactics for Sensory Disabilities, Psychoeducational and Didactic Action in Behavioural Disorders, Psychoeducational and Didactic Action in Relational Disorders, Non-verbal Languages and Communicative Techniques, Methods and Didactics for Motor Activities.

Internship is actually specific to the professional area and it is aimed at reprocessing personal experience and organising professional competencies by means of «direct» and «indirect» working practice.

Direct internship is to be completed in not less than 5 months and is carried out in the schools; it is observed by the interns' tutor, chosen among the teaching staff of the scholastic institution. The activities can include operational procedures based on "project work" proposed by the universities or the scholastic institutions. The projects pay particular attention to the professional growth of the active operators in the institution involved in the process and are coherent with the aims of the specialist training course for support activities.

Indirect internship includes supervisory activities on the part of the course teachers, that is the workshop teachers and the intern tutors at the universities and the places of internship respectively. Such activities concern reprocessing professional experience, and reprocessing this experience from a personal and psycho motivational point of view. Among the indirect internship activities, there is practical activity. In the use of new technologies applied to special didactics.

\section{LOCAL RESOURCES FOR SCHOOL INCLUSION}

Information concerning accessing services for children, and how they work, is provided by the Multidisciplinary Unit of the ASL, which also supplies information concerning certification procedures for disability, health and social assistance and rehabilitation. As well as information services and counselling, the Multidisciplinary Units also have teams of professionals with dif- 
ferent skills and expertise, such as psychologists, infant neuropsychiatrists, speech therapists, rehabilitation therapists, etc.

Information concerning enrolling for nursery and infant school and general organization are supplied by local authorities, through the services for social and integration policies, regional and provincial education offices, and also individual schools supported by Territorial Support Centres (CTS) and Territorial Inclusion Centres (CTI), currently in the process of reorganization and development. The CTS and CTI are, and will always be, more and more important for the optimal organization of school integration because, equally distributed across the nation, they are points of reference for schools and they coordinate their activities with local authorities, health services, associations of disabled people and their families. These associations have even established documentation, training or research centres, in accordance with the general strategies defined at the level of the regional school offices and MIUR. The associations and organizations across the nation play an important role, providing information and counselling at their locations. Some provide information specifically for families of children with particular disabilities or syndromes e.g. the Associazione Italiana Persone Down (the Italian Association for Persons with Down Syndrome), the Associazione Nazionale Famiglie di Disabili Intellettivi (the National Association of Families of the Mentally Disabled), the Associazione Nazionale Genitori Soggetti Autisitici (the National Association of Parents of Autistic Subjects), the Ente Nazionale Sordi (the National Authority for the Deaf), Famiglie Italiane Associate per la Difesa degli Audiolesi (Associated Italian families for the Defence of the Hearing Impaired), the Associazione Nazionale Famiglie Minorati della Vista (the National Association of Families of the Sight Impaired) and the Unione Italiana Ciechi (Italian Union for the Blind) etc. These are bodies and associations that contribute effectively to the process of educational and social integration of people with disabilities.

\section{THE INTEGRATED ITALIAN SYSTEM AND THE NETWORK OF SERVICES: RESOURCES FOR INFANT SCHOOL}

In the inclusive perspective which characterises the Italian school, the choice of building a network of services (Mantovani, 2002; Musatti \& Mayer, 2003) presupposes the idea of an integrated training system, or rather the idea of a system which places centrally, not a specific institution nor a specific educational agency, but the child as a person. He is not defined in a stereotypical way, but seen as constantly developing in the complexity of his existential 
dimension and the many relationships he gradually builds up in the community of life. For infant school, this network of services, if accepted from an ecological perspective, can be considered as a real and proper integrated training system. It responds, therefore, to the needs of the families and all the children and it certainly has, as an objective, the prevention of forms of alienation and exclusion by aiming to favour the growth of each in a personorientated society. It presupposes the assumption of an interdisciplinary and inter-institutional point of view because every action, to be efficacious, is placed at a crossroads of different systems among which not only scholastic and educational systems and the family are found, but also psycho-social and health systems. These are interdependent, and thus at the service of the person and at the service of the child, who is always the end-user and never the means. These interdependent links are, in fact, very important and it is above all fundamental to underline the importance of synergic interaction between workers and professionals in the same service and workers and professionals in different services, constantly aware that the interaction and the relationships between them are not always easy to realise nor are they a spontaneous and automatic process. The systematic synergy of actions, fundamental for the development of a disabled child, require space in which to share objectives, assess progress, newly direct action, and resolve conflict. In the integrated system, in fact, the "places» institutionally oriented for infancy are places of organised teaching, of the acceptance of diversity and care, of innovation and socialisation, of planning and experimentation. Services for infancy overall today are seen as educational contexts of high training validity and a system of complex relationships in which the roles of pedagogue and teacher are becoming more and more important. From this point of view, Framework Legislation no. 104/1992, among its fundamental objectives to guarantee disabled people's rights (Article 5, comma g), poses the realisation of a decentralisation of services and actions aimed towards prevention, support and the rehabilitation of the handicapped person, assuring coordination and integration with the other nationwide services, based on the Agreements of the programme in Article 27 of Law no. 142 (8th June 1990). Among the legislative measures which have successively contributed to the construction of the integrated training system in a relevant way, reference is given here to some fundamental measures of the Italian State developed according to a very decentralised design, coherent with the framework of institutional competencies and with the conviction that different subjects must be related to each other in the plan for a unified policy and an integrated system of action. This plan is also intended to defend the weakest subjects (handicapped children and adolescents) from difficulties of various origins and socio-cultural hardship. 
First of all, Law no. 285 (28th August 1997) Regulations for the promotion of rights and opportunities for infancy and adolescence envisages precise lines of action to promote the rights and well-being of minors, a group which has never had full political and administrative citizenship until now. The law emerged from the attention given internationally to the theme of minors at a UN Convention on the rights of infancy, and it is one of the most significant regulatory acts in the national action plan made enforceable by Law no. 17 (27th May 1991), and Articles 1 and 5 of the above-mentioned Framework Legislation no. 104 (5th February 1992). Other regulatory acts can also be added to the above legal instrument arising from the Convention, first among which is the Plan of Global Action for Infancy, the programme document and the "guide» for drawing up National Plans for infancy. The significant institution that Law no. 285/1997 envisages is a national Fund for infancy and adolescence at the offices of the Prime Minister, which has the aim of working on a local, regional and national level, in the light of projects presented by local authorities within the project area following the specific aims of the law itself. The fund started off among the regions and the autonomous provinces of Trento and Bolzano. A quota of $30 \%$ of the resources of the Fund is reserved for financing measures to carry out in the Municipalities of Venice, Milan, Turin, Genoa, Bologna, Florence Rome, Naples, Bari, Brindisi, Taranto, Reggio Calabria, Catania, Palermo and Cagliari. Among its aims are the "realisation of services of preparation and support for parentchild relationships, contrasting poverty and violence, as well as alternative measures for the admission of minors into educational-welfare institutions, bearing in mind, moreover, the conditions of foreign minors». The law envisages, at comma e), the possibility of funds for projects directed specifically towards the temporary acceptance of minors with psychological and sensory disabilities, in small educational rehabilitation communities. The aim and objective of this law, through receiving funding, is to realise and favour the promotion of rights, the quality of life, individual realisation and development and the socialisation of infancy and adolescence, favouring the environment most congenial for this, in other words, a foster, adoptive or natural family. Having established the responsibilities of the offices of the Prime Minister on a national level, the different conditions for the applicability of the law envisage that, on a regional level, every three years, local usage is defined by each region. The Territorial Technical Group operates within the limits of the needs identified, according to the priorities of the area. Guidelines are defined, and forms of coordination between different subjects who are creating projects formalised in accordance with the programme are identified. Every area works out a three-year action plan in favour of the subjects in the phase of development they wish to protect. It is their instru- 
ment for local planning, defining the system for promotion and protection. It contains objective and analytical elements, specifies the expected results, identifies projects, plans resources and puts responsibilities and services into the network. At local authority level - municipalities and associated municipalities according to Articles 24, 25, and 26 of Law no. 142 (8th June 1990), and small grouped mountain communities and provinces -, they represent the titular subjects themselves of projects, put them into action immediately, and make up the three-year action plan in each area. The local authorities are requested to start the planning and participate in its management, as well as stipulate agreements with the plan, coordinated by a leading authority. Successively, Law no. 451 (23rd December 1997) Establishing a Parliamentary Commission for infancy and a National Observatory for infancy, was issued with the aim of coordinating measures concerned with infancy and adolescence between the state and the regions, linking the regions with provincial administrations and the autonomous provinces of Trento and Bolzano. Among the local coordination activities of collecting and processing all the data relating to infancy and adolescence regionally, particular reference is made to the acquisition of data relating to the social, cultural, economic, health and psychological conditions of infancy and adolescence, to financial resources and their destination, to participating areas in the sector, to maps of services in the area and the resources supplied by private individuals or groups. The law, therefore, is the provision with which the Italian state activates the principles of the UN International Convention on the Rights of the Child and it represents one of the legislative initiatives which make up the Action Plan and measures for the protection and development of subjects in phase of development (Article 2). This could be interpreted as a proposal for a process to organise communities, envisaging a precise procedure for its activation. The Action Plan, to be defined every two years, is at the disposal of the National Observatory for Infancy and Adolescence. The Observatory launches a vast range of legislative and administrative measures and cultural offers to be carried out in those two years, in close collaboration with the central institutions of the state, the regions, the municipalities and the active participation of private social forces, volunteer groups, associations, NGOs, from civil society and in connection with the Institutions of the European Community. The central administration of the state, the regions and the local authorities coordinate, therefore, with the Observatory so that every measure intended to qualify for financial commitment is adopted in order to pursue the priorities and actions envisaged by the plan itself. The State-Regions agreement, approved 20th March 2008, proposes a very different way to take responsibility for the disabled pupil and moves away significantly from the procedural plan, even if it is coherent with its cultural principles. The agreement, in fact, outlines 
a procedure inspired by respect for the disabled person and his family, aware of the role expected from the school in dialogue with specialists in the multidisciplinary team from the local health authorities. Explicit reference is made to WHO's ICF as a favoured instrument for the interpretation of needs; it proposes an innovative model of usage to specialised support teachers, and also considers the responsibility that the scholastic institution has for both planning and educational action. Moreover inter-institutional collaboration is reinforced between the various groups involved.

In the following, elements of greater interest are listed:

- Simplifying the certification process. It is established that, for pupils who are already in the care of the local health authority, initial certification for school enrolment is enough. This certification becomes the base for the educational and didactic activities which the school will programme and carry out.

- Drafting a functional diagnosis by a multidisciplinary unit in the specialist services for infancy and adolescence. This is a dynamic appraisal for entry, taking responsibility for the person according to the criteria in the ICF.

- Developing the functional diagnosis, which contains what used to be the functional dynamic profile, and which involves both the family and experts in special didactics. The functional diagnosis must be updated when passing from one grade to another at school.

- Drawing up an individualised educational plan by the teaching staff at infant school, as in other scholastic grades (inter-sectional/interclass/class meetings) together with the parents. This method allows the acquisition of all the necessary resources sufficient for the process of individualised support.

- Assessing the PEI annually, at an intermediate phase and in the final phase to facilitate revision of the direction of education and training. This cannot be limited to a simple sequence of didactic units organised ad hoc, but by choosing didactic, organisational and educational conditions, prioritising «collaboration between all the staff involved in reaching certain shared objectives".

- Assuming the perspective of a diachronic orientation with respect to both the search for a more suitable formative path for the single person, and the promotion of the Life Plan and ways to complement adulthood and working life.

- Carefully assigning professional resources and materials which go beyond the limits of purely mechanical certification, but introduce the logic of the planning dialogue and collaboration between institutions.

Framework Legislation no. 328 (8th November 2000) Framework Legislation for the realisation of an integrated system for projects and the social ser- 
vices, promotes action to guarantee the quality of life, equal opportunities, non-discrimination and rights to citizenship. It attempts to prevent, eliminate or reduce conditions of disability, of need and individual and family poverty, deriving from inadequate income, social difficulties and conditions of lack of autonomy, according to Articles 2, 3 and 38 of the Constitution. The integrated system of action and social services is carried out through policies and coordinated services in different sectors of social life. This integrates services for the person and the nuclear family with possible economic measures, and the definition of active ways to optimise the efficiency of resources, avoiding overlapping competencies and sectorialisation of responses. To this end, multiple financing is offered, according to differentiated competencies and with pertinent financial endowments from the respective balances of the local authorities, the regions and the state. The law envisages drawing up a national plan for measures and the social services, set down by the Council of Ministers on the proposal of the Minister for Social Solidarity, and after hearing the Ministers in charge, as well as the Unified State-Regions Conference. Finally, transmitted to both Houses, the plan envisages the realisation of programmes for the support of minors with disabilities in various areas of social life, aiming for their full integration. On the 12th July, 2012, the Ministry of Education, Universities and Research stipulated a Memorandum of understanding to safeguard the rights to health and study of pupils and students with disabilities. The Sections, as Article 2 recounts, are dedicated to promoting, sustaining, and developing initiatives intended to ensure global responsibility for children, pupils and students with disabilities and specific developmental disorders, guaranteeing them integrated measures. To this end, the Sections convene to reinforce institutional collaboration, including plans for ordinary training to improve, coordinate and facilitate activities of respective competencies in the process of scholastic inclusion, with the objective of guaranteeing, as much as possible, rights to health and education. One of the understandings regards the promotion and support of initiatives intended to favour the early diagnosis of disabled children at pre-school age, as well as the development of actions directed towards some relevant specific types of disability and developmental disorders, in the logic of a system which integrates a clinical approach with a psycho pedagogical one.

Another important aspect is also the dedication to the progressive application of the World Health Organisation's International Classification of Functioning, disability and health model (ICF), conveniently suitable for the Italian situation and the specifics of the Italian model for scholastic inclusion. In December 2012, MIUR sent out a directive, Nationwide organisation for scholastic inclusion and measures for action for Special Educational Needs (SEN) which supports the need for a new organisational model for school integra- 
tion and responsibility for SEN on the part of the teachers able to guarantee the efficacy of the measures. The Area support centres (Centri Territoriali di Supporto: CTS) are strategic from this point of view as they represent an interface between the administration and schools of every kind and level, and between the schools themselves as far as SEN is concerned. The CTS collaborate, therefore with other area resources in creating a support network for the integration process, with particular reference to scholastic empowerment by means of the new technologies, but also by cooperatively offering help to teachers. To be brief, one can deduce that an 'integrated' system exists which covers almost all needs, with some common rules, also due to the Parity Law. The didactic models, however, are not homogeneous. In fact, they differ very much from area to area and from manager to manager, by reason of cultural convictions, or cultural and social ends but, above all, they differ in the overall quality of the service.

Structural situations relating to buildings, support services, canteens, and equipment are still not satisfactory. To face these critical points and, at the same time, work towards a generalisation of quality elements seems to be a suitable model for improvement.

\section{From NURSERY TO INFANT SCHOOL: THE IMPORTANCE OF EDUCATIONAL CONTINUITY}

In the inclusive perspective described so far, moving on from nursery school ${ }^{12}$ to infant school, or from the latter to primary school has a fundamental role, which can also be made more efficient and harmonious through moments of common experience and training between social workers and teachers.

For the latter, as far as the passage between nursery school and infant school is concerned, the action they take is fundamental, associated with the same educational tension and knowledgeable planning directed towards the global development of the child, even if he is different in his educational prospects.

Framework Legislation no. 104/1992 highlighted, in reference to prevention and early diagnosis (Article 6, comma h), the need for coordina-

12 The first public nurseries in Italy were set up in accordance with Law 6th December 1971, and their management was entrusted to the Municipalities. With the Law no. 285 (28th August 1997) Regulations for the promotion of the rights and opportunities for infancy and adolescence, different types of socio-educational services for early infancy (0-3 years) were identified, not in substitution of the nursery, but rather as new educational offers to families in an ample countrywide system of services for infancy.

ECPS Journal - 12/2015

http://www.ledonline.it/ECPS-Journal/ 
tion between nursery schools, infant schools and compulsory schools. Furthermore, to guarantee educational continuity between the different school levels in order to activate integration (Article 14, comma c), the same law set down obligatory forms of consultation between teachers of both the lower and upper cycles and the maximum development of scholastic experience of the handicapped person in all orders and grades of school, allowing him to complete compulsory schooling, even up to the eighteenth year of age. Nursery school, therefore, from being an environment for safekeeping and assistance has acquired a more and more educational value guaranteeing the harmonious development of the child, relevantly contributing and inserting itself with full rights among the promoters of a new culture of infancy. To this end, an agreement framework was reached for the realisation of a offer of educational services in favour of children from two to three years old, intended to improve links between nursery and infant school and to contribute towards countrywide development of social-educational services 0-6 years, according to Article 9, comma 2, letter c) of the Legislative Decree no. 281 (28th August 1997).

This agreement, sanctioned for the first time experimentally at the Unified State-Regions and Local Administrations Conference on the 14th June $2007^{13}$ and confirmed at all the following Unified Conferences, envisages setting up «Spring Sections» [Sezione Primavera] for children aged between 24 and 36 months, with joint financing from the Ministry of Education, Universities and Research (12m for 2014/2015) and the regions. The offer of an educational service for children aged between 24 and 36 months, even with disabilities, is to be understood as an integrative socio-educational service, linked to the current schools of infancy and nursery schools ${ }^{14}$. Managers of

13 The measure by the Unified State-Regions Conference (14th June 2007), Understanding between the Minister for Policies for the Family, together with the Minister of Education, the Minister of Social Solidarity, and the Minister for Rights and Equal Opportunities, the regions, the autonomous provinces of Trento and Bolzano, the provinces, the municipalities and small grouped mountain communities, made Article 1, comma 1259, of the Law no. 296 (27th December 2006) active for the assignment of a part of the sums intended for the realisation of an extraordinary intervention plan for nationwide development of educational services and financing in accordance with that stipulated on the same date for the realisation of an experimental and integrated educational offer for children of two to three years old, according to Article 1, comma 630, of the Law no. 296 (27th December 2006). Understood in the meaning of Article 8, comma 6, of the Law no. 131 (5th June 2003 - Acts Register no. 48/CU).

14 In more «mature» Italian realities, we refer to the experience of Emilia-Romagna, the high quantity of educational services 0-3 (near the European standard) made possible by the coexistence of an abundance of solutions: Reggio Emilia and Forli, where the coverage $0-3$ surpasses $40 \%$, a quota of the service is guaranteed really by the diffusion of the Spring

ECPS Journal - 12/2015

http://www.ledonline.it/ECPS-Journal/ 
state, municipal and recognised infant schools, as well as municipal nurseries or those with authorised subsidies can apply for the activation of the services of the Spring Sections. Coherent with the principle of educational continuity, this offer supplies an answer to the requests of families for services for early infancy, and contributes to the diffusion of a culture careful of the needs and potential of children from 0-6 years. This takes advantage of the positive experiences which have already taken place in numerous areas, with the prospect of planning all other relevant experiences which may be educational services for children of that age, with respect to the current regulations.

The educational projects for Spring Sections, in order to ensure the quality and good functioning of the service, must respond to the following general criteria laid out in point 5 of the Agreement:

- to respect the ratio between educator and child at no more than 1:10;

- to enroll children of only 24 months old by 31 st December;

- to externalise services is not allowed, except for those stipulated by the local authorities;

- to respect the maximum number of children per section;

- to present a precise and not generic educational plan.

With reference to this last requirement, the Agreement stipulates that educational projects, in order to ensure the quality and functioning of the service, must respond to general criteria with respect, however, to regional regulations. These are specifically:

- to have a suitable space, both from the points of view of function and safety, responding to the diverse needs of children (reception, rest, play, feeding, personal care);

- to have furnished spaces;

- to use materials able to qualify the educational environment as a context of life, of relationships and learning;

- to have a specific plan to update the staff for educational continuity: planning links/continuity and connections to educational processes in specific ways;

- to have a flexible working timetable which envisages an hourly module from between 5 and 8 hours a day;

- to have a numerical ratio of pedagogues to children which, according to regional laws, should not be superior to $1: 10$;

- to have a contained group at a "homogeneous» age, which can vary from between 10 to 20 children, on the basis of the educational and organisational model adopted.

Sections based on regional legislation and reference to the work of private groups, particularly the Federation of Italian Nursery Schools (FISM). 
These are undeniable requisites which make up the basic conditions for authorising the setting up of Spring Sections, for the continuation of their activities and, after assessment, for consequent public funding. The most recent agreement, stipulated for 2013/2014, confirms the full involvement of the various institutional partners and envisages directed control, and a scientific control committee among the interested parties (MIUR, Regions, Departments of Policies for the Family, the Ministry of Employment and Social Policies, Local Administrations), for whom MIUR acts as promoter to streamline the bureaucratic process necessary for the establishment of these organisms. As far as the distribution of funds is concerned, MIUR and the regions annually put certain financial resources aside. The Department of Policies for the Family, and the Ministry of Employment and Social Policies reserve for themselves the possibility to put aside a quota of financial resources based on the funds available. Together, state contributions start at about 50\%, based on the population from 24-36 years old, resident in Italy, and the remaining $50 \%$ based on the number of authorised sections. On the occasion of regional understanding, general criteria for the contribution requested for families are defined, envisaging that it is contained, by law in a parametric bracket which can be found between the quota requested in the area for attendance at infant school and that requested for municipal nurseries, as envisaged in the Agreement of 14th June 2007. The municipalities, instead, are responsible for the functioning of the Spring Sections with their own contributions, decided autonomously, of instrumental and human resources and services. In conclusion, one can state that even today, it is still necessary to solve both the problem of stability and the contractual uniformity of the employed workers. At the moment, there are many different solutions nationwide, and a definition of a specific professional profile of those who work in the Spring Sections is also needed. As far as these aspects are concerned, the trades unions have also attracted attention to the forms of management in the Spring Sections, so that the charitable aspect does not prevail over the educational and developmental one which, however, is a more suitable way to describe them. For this reason, for their functioning, the regional school offices, based on criteria supplied by the Ministry of Education, Universities and Research, stipulate appropriate understandings with the respective regions, after having consulted the National Association of Italian Municipalities, for the use of state and regional funds (Article 4). The regions envisage programming Spring Sections nationwide. In the census of 22nd August 2011, 1.459 Spring Sections were monitored; 91\% of the 1.604 sections in the census (state, recognised, private or run by the municipality) gave the figures shown in the following tables (Tables 2-3). 
Table 2.

\begin{tabular}{cc}
\hline SPring SeCtions ACTIVATEd & CHILDREN From 24-36 MONTHS OLD \\
\hline 1604 & 25000 \\
\hline
\end{tabular}

Source: MIUR, Monitoring 2010/2011 - Table 4: Spring Sections and children attending.

Table 3.

\begin{tabular}{lrcc}
\hline & \multicolumn{2}{c}{ SPRING SECTIONS } \\
\hline & Census & Monitored & $\%$ \\
\hline Liguria & 106 & 106 & $100.0 \%$ \\
Emilia Romagna & 85 & 84 & $98.8 \%$ \\
Puglia & 176 & 173 & $98.3 \%$ \\
Lazio & 137 & 133 & $97.1 \%$ \\
Abruzzo & 30 & 29 & $96.7 \%$ \\
Marche & 25 & 24 & $96.0 \%$ \\
Lombardia & 266 & 248 & $93.2 \%$ \\
FriuliVenezia Giulia & 40 & 37 & $92.5 \%$ \\
Umbria & 29 & 26 & $89.7 \%$ \\
Basilicata & 38 & 33 & $86.8 \%$ \\
Campania & 150 & $86.7 \%$ \\
Piemonte & 63 & 63 & $86.3 \%$ \\
Veneto & 73 & 63 & $85.1 \%$ \\
Calabria & 74 & 50 & $84.7 \%$ \\
Sardegna & 59 & 61 & $83.6 \%$ \\
Toscana & 73 & 53 & $82.8 \%$ \\
Sicilia & 64 & 85 & $81.0 \%$ \\
Molise & 105 & 41 & $80.4 \%$ \\
\hline Total & 51 & 1459 & $91.0 \%$ \\
\hline
\end{tabular}

Source: MIUR, Monitoring: 2010/2011 - Table 5: Monitored Spring Sections for Region.

Table 4.

\begin{tabular}{lrc}
\hline & ArEas & SECTIONS With WAiting Lists \\
\hline North west & 141 & $33.8 \%$ \\
North East & 44 & $23.9 \%$ \\
Central & 74 & $31.5 \%$ \\
South & 222 & $46.6 \%$ \\
Islands & 57 & $39.0 \%$ \\
\hline Total & 540 & $37.0 \%$ \\
\hline
\end{tabular}

Source: MIUR, Monitoring: 2010/2011 - Table 6: Spring section with waiting list for geographical areas. 
More than a third of the Spring Sections monitored (540, equal to 37\%), at the beginning of activities had a waiting list. Of these, more than $40 \%$ of the total (222 units) were in the southern regions. Relating to the functioning Spring Sections, the 222 sections with a waiting list, concerning almost half $(46.6 \%)$ of the Spring Sections, were in the south, evidence of the still limited diffusion of services for infancy (Table 4).

It is also evident that other sections, with a total of 10,000 children, do not respond to the quality parameters requested and therefore are not financed, but do exist in the areas. Consequently, even with the prospect of development and nationwide expansion, with the aim of supporting the qualification of educational services and the assessment of their fulfilment, organisms of support are confirmed:

(a) In the national office, where the joint group directs the project, with the functions of monitoring, linking and coordination. They make use of technical and scientific competencies for carrying out their responsibilities, put at their disposition by diverse institutional partners. These competencies include acquiring data and checking accounts, assessing and acquiring experience. Therefore, it is possible to distinguish criteria for improvement for the possible stabilisation of the service, to be carried out compatibly with, but depending on, the availability of financial resources.

(b) In the regional offices. Here, the technical board for evaluation and comparison, set up on the basis of ways defined by single regional understandings, aims to direct, assess and provide possible support for the experience.

(c) In the local office, where the Town Hall is recognised as the «regulator» of the new educational offer, in the framework of planning and regional regulations.

The Table 5 shows the presence, even though it is a very low number, (102, equal to $0.44 \%$ ) of the Spring Sections with disabled children. The situation is quite homogeneous nationwide.

Table 5.

\begin{tabular}{lcc}
\hline & ArEas & Disabled ENROLLED \\
\hline North west & 28 & $0.42 \%$ \\
North east & 13 & $0.48 \%$ \\
Central & 21 & $0.57 \%$ \\
South & 27 & $0.35 \%$ \\
Islands & 13 & $0.56 \%$ \\
\hline Total & 102 & $0.44 \%$ \\
\hline
\end{tabular}

Source: MIUR, Monitoring 2010/2011 - Table 7: Children with disabilities - Spring Section for geographical areas. 
Preliminarily, monitoring revealed the location of the Spring Sections compared with the other educational structures, considering that the founding law (no. 296/2006), refers clearly to experimental sections aggregated to kindergartens. Nearly $82 \%$ of those sections are located inside the infant school (kindergartens). 14.4\% are located inside the crèches, and the most affected areas are in the Eastern-Northern and the Central Regions. In Umbria, Tuscany and Emilia Romagna Regions about one third of the Spring Sections are located inside the crèches; about 35\% in Umbria, about 30-32\% in Tuscany and in Emilia Romagna. The remaining 6\% is located inside other schools or other specific buildings. In Southern Italy, most of the Sections are located inside the kindergartens $(87 \%)$, but there is also the lowest percentage of Sections inside the crèches $(6.5 \%)$ because of the low presence of such structures in those areas.

In the Eastern-Northern and the Central Regions, the aggregation of the Sections to the crèches is widespread, more than in other territories (one section out of five; Table 6).

Table 6.

\begin{tabular}{lrccc}
\hline \multicolumn{1}{c}{ Areas } & $\begin{array}{c}\text { Nursery } \\
\text { SCHOOL }\end{array}$ & Kindergarden & $\begin{array}{c}\text { Other } \\
\text { EDUCATIONAL } \\
\text { STRUCTURE }\end{array}$ & $\begin{array}{c}\text { Other } \\
\text { STRUCTURE }\end{array}$ \\
\hline South & $6.5 \%$ & $87.0 \%$ & $3.8 \%$ & $2.7 \%$ \\
Islands & $14.4 \%$ & $81.5 \%$ & $2.7 \%$ & $1.4 \%$ \\
Noth West & $13.9 \%$ & $81.1 \%$ & $3.4 \%$ & $1.7 \%$ \\
North East & $23.4 \%$ & $72.3 \%$ & $2.7 \%$ & $1.6 \%$ \\
Center & $20.8 \%$ & $70.8 \%$ & $6.8 \%$ & $1.7 \%$ \\
\hline Total & $13.8 \%$ & $80.3 \%$ & $3.9 \%$ & $2.0 \%$ \\
\hline
\end{tabular}

Source: MIUR, Monitoring 2010/2011 - Table 8: Placement of spring sections by educational structures in the geographical areas.

The 7th October 2010 Agreement does not expressly refer to the hourly duration of the functioning of the Sections, but refers to the general criteria expected from point 5 of the 5th June 2007 Agreement, where it implicitly confirms its limits as follows: «[...] a flexible functioning timetable includes a basic module (up to 6 hours) and extended hours (up to 8/9 hours)». Following this, a Directorial Decree (no. 37, 10th April 2008), on the advice of the National Technical Group, specified that such a timetable would be «included, in principle, between 5 and 9 hours daily». Such criteria were confirmed up to 2010, broadly orienting the organizational choices of the Sections. However, as can be 
deduced from the survey, there are profound differences between the different geographical areas regarding the functioning timetable: in the Southern Regions and in the Islands about $30 \%$ of the Sections work for up to 6 hours daily. In Calabria, 32\% of the Sections work just 4 hours a day and $20 \%$ for 5 hours a day (Table 7 ).

Table 7.

\begin{tabular}{lcrrrrc}
\hline \multicolumn{1}{c}{ ArEas } & 4 HOURS & 5 HOURS & 6 HOURS & 7 HOURS & 8 HOURS & 9 HOURS \\
\hline Noth West & $0.0 \%$ & $1.7 \%$ & $5.8 \%$ & $22.1 \%$ & $31.7 \%$ & $38.8 \%$ \\
North East & $0.5 \%$ & $3.8 \%$ & $7.6 \%$ & $10.9 \%$ & $47.3 \%$ & $29.9 \%$ \\
Centre & $0.4 \%$ & $6.8 \%$ & $8.1 \%$ & $16.2 \%$ & $39.6 \%$ & $28.9 \%$ \\
South & $4.4 \%$ & $12.7 \%$ & $12.0 \%$ & $31.6 \%$ & $27.8 \%$ & $11.4 \%$ \\
Islands & $1.4 \%$ & $17.1 \%$ & 17.1 & $34.2 \%$ & $19.2 \%$ & $13.0 \%$ \\
\hline Total & $1.7 \%$ & $7.7 \%$ & $9.5 \%$ & $24.0 \%$ & $32.4 \%$ & $24.6 \%$ \\
\hline
\end{tabular}

Source: MIUR, Monitoring 2010/2011 - Table 9: Timetable for geographical areas.

The most important differences regarding scheduled time for rest compared to the National hourly average were recorded in the Northern Sections more than one fifth of the whole functioning daily hours - (referring particularly to the extended hourly duration); in the Southern areas, on the other hand, time for rest was much more reduced also because of their daily parttime organization.

In the Southern Regions, time for free playing activity is also much more common (in the Islands up to one fourth of the whole year's timetable, that is to say six and three-quarter hours; Table 8).

Table 8 .

\begin{tabular}{lccccccc}
\hline \multicolumn{1}{c}{ Areas } & Welcoming & $\begin{array}{c}\text { Educational } \\
\text { AND Didactic } \\
\text { ACtivities }\end{array}$ & $\begin{array}{c}\text { Free } \\
\text { EDuCational } \\
\text { ACtivities }\end{array}$ & $\begin{array}{c}\text { Lunch } \\
\text { SNACK }\end{array}$ & Relax & More & $\begin{array}{c}\text { Total } \\
\text { Hours }\end{array}$ \\
\hline Noth West & $15.2 \%$ & $21.7 \%$ & $19.6 \%$ & $15.4 \%$ & $21.9 \%$ & $6.1 \%$ & 8.0 \\
North East & $15.7 \%$ & $21.2 \%$ & $19.0 \%$ & $16.7 \%$ & $21.3 \%$ & $6.1 \%$ & 7.9 \\
Centre & $16.3 \%$ & $26.2 \%$ & $19.7 \%$ & $16.5 \%$ & $16.9 \%$ & $4.3 \%$ & 7.7 \\
South & $15.5 \%$ & $27.8 \%$ & $22.1 \%$ & $16.1 \%$ & $12.5 \%$ & $6.0 \%$ & 7.1 \\
Islands & $16.8 \%$ & $27.7 \%$ & $24.2 \%$ & $15.4 \%$ & $11.9 \%$ & $4.0 \%$ & 6.8 \\
\hline Total & $15.7 \%$ & $24.8 \%$ & $20.7 \%$ & $16.0 \%$ & $17.2 \%$ & $5.6 \%$ & 7.5 \\
\hline
\end{tabular}

Source: MIUR, Monitoring 2010/2011 - Table 10: Activity time of a typical school day (in percentage respect to the whole daily hours). 
As far as the passage from infant school to primary school is concerned, it is to be underlined that the latter, because of its educational and didactic aims, is concerned with the ease of access of its disabled pupils also during pedagogical, curricular and organisational linking with infant school, continuing to endorse experiences with active educational approaches and progressively accompanying the children along paths oriented to subjects and to connections in knowledge. Such coordination also guarantees educational continuity between different types of school with the aim of activating integration (Article 14, comma c). The same law envisages obligatory forms of consultation between teachers of the upper and lower cycles, and the maximum development of the scholastic experience of the handicapped person in all types and grades of school, allowing completion of compulsory schooling even up to eighteen years old.

To this end, Law no. 104/1992, other than envisaging, as has been said above, obligatory forms of consultation and coordination between the teachers in all types of schools, gives great relevance to drawing up the functional diagnosis and the successive functional dynamic profile with the aim of putting into evidence, above all, the principle potential areas at the phase of development considered, other than the difficulties. In this way, the treatment to be carried out in the framework of the educationaldidactic programming of the section and of the individualised educational plan for which the teachers are responsible, more suitably correspond to the needs and the abilities of each single child (Article 12). Such actions aim to promote maximum autonomy, the acquisition of competencies and expressive and communicative abilities and, where possible, the possession of linguistic and mathematical basics. It is very important that continuity is not only an element for connections, as in updating the functional dynamic profile when finishing infant school ${ }^{15}$ but it is above all a constituent element of educational action at every phase, making use of flows of information and descriptive and evaluative data to set up adequate paths for learning, suitable for the single individual and favouring full participation in school life.

Among the fundamental elements promoting continuity in the process of integration are the following:

- Transmitting information and data on the pupil, which is easily and univocally decodifiable by the receiver and who has to use it. To this end, direct observation procedures of the child are carried out in formal and informal situations to note possible relational dynamics with adults and peers, and

15 The functional dynamic profile is updated at the end of nursery school, elementary school, middle school and during the course of instruction at secondary school. 
his habits, and also, at the same time, to note his time-school organisation and environment building.

- Identifying aims and common objectives.

- Progressively harmonising with didactic methodologies and strategies, care in the practice of teaching.

- Adopting the common language used by teachers.

- Reciprocally knowing the National Recommendations for the curriculum relating to respective school levels and assuming the curricular perspective.

- Attending training courses for scholastic integration in which curricular and support teachers are involved from both infant and primary schools.

- Collaborating between teachers of infant and primary school, with particular regard to the move from one to the other, both to acquire information on a disabled child and the related documentation, and to identify a group of classmates with whom he can move to primary school.

- Collaborating with the family to enrich an informative framework on specific aspects of the child (personality, attitudes, interests, preferences, desires etc.), consequently creating trust and mutual esteem.

- Collaborating with the appropriate services in the area through meeting the psycho-social-health workers who care for the child, with the aim of acquiring knowledge both on the diagnostic profile and also on the therapeutic and rehabilitation programme. This means meetings based on interinstitutional collaboration, which is systematic in the operative work group for handicap (GLHO).

- Organising ways to receive the disabled child in a new school context. Managing activities for groups of children and their teachers from the respective scholastic orders is fundamental to create early knowledge of a new school environment through efficacious mediation with the pupils themselves and also to prepare the best conditions (time, space, resources) so that the child can fully realise his potential.

\section{ECONOMIC RESOURCES FOR INFANT SCHOOL}

Funds are, in general, provided by the Ministry of Education, Universities and Research, through the regional and provincial education offices for both state schools and officially recognised private schools. For schools operated by the municipalities, the funds are provided by the municipalities themselves through the appropriate agencies.

Additional funding may come from participation in specific projects proposed by MIUR or by local authorities as well as other national or inter- 
national bodies. To this end, special public announcements are published, as individual institutions may adhere with the presentation of their own projects. The latter are then evaluated by a commission appointed by the institution that issued the announcement. The commission selects participating schools in the light of requirements according to predefined criteria and observe the whole implementation of the project. During this observation, the commission takes part in scheduled meetings with contacts/project managers to provide systematic feedback, gives guidance for improvement and monitors the evolution of the projects themselves. Funds are disbursed throughout after checking consistency between the quality and quantity of what has been said and what has been achieved. In schools, some teachers deal with studying the announcements, and make proposals to the school board for projects to be carried out by all or only some of the teachers. Participation is decided by the school board. Even in the absence of additional funds, the implementation of the integration process proceeds without uncertainty, as a result, challenging school re-organization to optimize the resources available, while recognising the financial hardship which will certainly affect potential improvements to school integration.

\section{Contextual factors: Barriers AND Facilitators TO SCHOOL INCLUSION}

In Italy, the debate on integration is very wide-ranging and subscribed to, especially with reference to the increasingly felt need to be able to count on real and continuous assistance from several institutions and individuals (the social and health services, families, schools, local authorities).

In Italy, there are examples of both effective and less effective cooperation. Among the factors that facilitate the inclusive education of children with disabilities, there is certainly qualified training of all teachers and school directors, and no longer just teachers for support activities. With this in mind, for some years, the Ministry of Education, Universities and Research has been involved in aiming to enable direct training for teachers and curricular school directors on issues of inclusive education throughout the nation.

These initiatives came to fruition in higher education; courses in Master's degrees and professional updating courses have been carried out in different regions of Italy by universities which have specific expertise in this area. This is especially true for the departments that offer degree courses in education and training, in which they are active in the disciplinary fields 
of science, including teaching Special Pedagogy and Special Didactics. Both higher education courses, whether Master's or refresher courses, are funded by MIUR and are offered free of charge to teachers serving in state schools and officially recognised private schools. Enrolment on these courses is for a limited number of participants (scheduled generally for 100 teachers in each highly-qualified Master's / professional training / professional updating course) and based on predefined criteria by MIUR and the universities. Each path has ongoing and final exams, according to the existing legislation. There are also many pupils with learning difficulties to be considered, not due to a disability, but who require specific action to remove and overcome these difficulties. Therefore, each school is committed to promoting the development of the potential of all parties that attend, and respond adequately to different special educational needs. For this reason, the ongoing debate in Italy highlights the need for schools to have teachers trained to meet all demands, even in the use of new technologies, as well as greater financial resources. From a general point of view, there is growing attention to the environmental factors described by the WHO (2007) International Classification of Functioning, Disability and Health - Children and Youth (ICF-CY) mainly because it shows the importance of increasing the aspects that favour integration (the "facilitators») and eliminating those that impede it (the «barriers»).

\section{SOME REFLECTIONS}

The highly integrative choice that Italy has decided to make for many decades is much appreciated. It is an irreversible choice that requires continual improvements to be made in the school context which includes a great diversity of subjects. This work asserts that the specific features of the children 3-6 aged (way of learning, relationship, importance of play etc.) give to infant school the possibility to be a real fully inclusive setting in which each child can take part in all school activities. Since infant school, it's very important that the children contributions have been valued and their individual achievement have been recognized. According to a recent research about school integration in Italy, the infant school's situation is, generally, rather positive and the weaknesses of Italian school seem to be less (Associazione Treellle et al., 2011).

One example of excellence in the quality of integration has been demonstrated for many years by the infant schools in the region of EmiliaRomagna. This region, in 1992, established a working group on the right to education for persons with disabilities and drafted a document that, even 
then, highlighted the need for both effective inter-institutional cooperation and specific work plans in order to meet particular needs. In the part of the document devoted to local authority employees, they state the need to initiate a selection process among non-teaching staff so that they can carry out tasks of «basic support». Moreover, it also promotes the opportunity for workers who are not teachers to carry out educational tasks in both infant school and in compulsory education. Another important point is also a recommendation for the construction of a network of documentation centres which can provide documentation, lifelong training and cultural support, as well as operational and educational integration projects, preferably with the help of a pedagogical worker with coordination functions for integration in the area. Another example of excellence is shown by the decisions taken by the Piedmont region with the resolution by the Regional Council, 1st February 2010 Integration guidelines for local health authorities, bodies managing social welfare functions, schools and vocational training institutions concerning the right to education, instruction and vocational training of disabled students or those with Special Educational Needs. The region has defined modalities for identifying students in a disability situation or with special educational needs by making use of the ICF Classification by WHO as a means of control for the purposes of integrated education and training and for educational programming and support activities.

The regulations contained in the resolution have been adopted since school year 2011/2012 by regional health authorities who participated with the authorities in regionally testing the ICF in their areas, exclusively for new situations or for those needing a profile revision/update. Since academic year 2012/2013 the procedures set down in this Act have been applied throughout the regional area for new cases and for updates.

\section{ANNEX}

Some principal research sources:

- The Constitution of the Italian Republic, 1948.

- UN, International convention on the rights of the child, 1989.

- UN, Convention on the rights of persons with disabilities, 2006.

- WHO-CY, International classification of functioning, disability and health. Version for children and youth, 2007.

Laws, Presidential Decrees, Legislative Decrees:

- Law 18th March 1968, no. 444, Establishment of the state infant school.

- Presidential Decree 1969, Guidance for educational activity in nursery school. 
- Decree Law 30th January 1971, no. 5, Providence in favor of the civilian disabled or invalids.

- Law 30th March 1971, no. 118, Enactment of Law Decree 30 January 1971, no. 5, and new rules in favor of the civilian disabled or invalids.

- Law 6th December 1971, no. 1044, Five-Year Plan for the establishment of municipal nursery schools with the assistance of the State.

- Law 22nd July 1975, no. 382, Norms on the regional and the organization of public administration.

- Presidential Decree 24th July 1977, no. 616, Implementation of the devolution of art. 1 of the Law 22th July 1975, no. 382.

- Law 4th August 1977, no. 517, Rules on the assessment of students and the abolition of remedial examination as well as other changes introduced in the school.

- Law 20th May 1982, no. 270, Revision of the regulations in recruiting teaching staff in nursery, elementary, secondary and artistic school, restructuring of its organisation, adoption of suitable measures to avoid creating temporary employment and reassignment of temporary staff to permanent posts.

- Law 8th June 1990, no. 142, Order of local governments.

- Law 19th November 1990, no. 341, Reform of university teaching.

- Law 27th May 1991, no. 176, Ratification and implementation of the Convention on the rights of the child.

- Framework legislation for the assistance, social integration and the rights of handicapped persons, no. 104/1992.

- Presidential Decree 24th February 1994, Policy and coordination on the tasks of the health units in the field of special needs education.

- Law 15th March 1997, no. 59, Government mandate to confer functions and duties to regional and local councils for the reform of the public administration and its administrative simplification.

- Law 28th August 1997, no. 285, Provisions for the promotion of rights and opportunities for children and adolescents.

- Legislative Decree 28th August 1997, no. 281, Definition and broaden the powers of the Permanent Conference for relations between the State, the regions and the autonomous provinces of Trento and Bolzano and unification, for the subjects and tasks of common interest of the Regions, the provinces and municipalities, with the Conference of StateRegions and local Authorities. In particular: article 9, paragraph 2, letter c, defined by the Agreement establishing the joint Conference State-Regions and local Authorities.

- Law 23rd December 1997, no. 451, Establishment of the Parliamentary Commission for children and the national childhood.

- Presidential Decree 8th March 1999, no. 275, Regulation concerning rules on the subject of autonomy in scholastic institutions, in accordance with Article 21 of the Law of the 15th March 1997, no. 59. 
- Ministerial Decree 3rd June 1999, no. 141, Training classes with students with disabilities.

- Law 10th March, 2000, no. 62, Rules concerning scholastic parity and regulations concerning the right to study and instruction.

- Presidential Decree 13rd June 2000, Approved national Plan of Action and interventions for the protection of the rights and development of subjects in childhood 2000/2001.

- Legislative Decree 18th August 2000, no. 267, Text of the Act on local Authorities for the implementation of measures requiring action more integrated and coordinated public for the fulfillment of the measures.

- Framework Law 8th November 2000, no. 328, Framework Law for the implementation of the integrated system of intervention and social services.

- Law 28th March, 2003, no. 53, Mandate to the Government for the definition of general rules on education and the fundamental performance levels for education and training.

- Legislative Decree 19th February, 2004, no. 59, Definition of the general rules relating to infant school and the first cycle of education [until the 3rd year of Middle School, 13/14 years old], according to Article 1 of the law of 28th March, 2003, no. 53.

- Presidential Decree of the Council of Ministers 23rd February 2006, no. 185, Regulation laying down the procedures and criteria to individuate with disabilities, in accordance with Article 35, paragraph 7 of the Law 27th December 2002, no. 289.

- Presidential Decree 7th April 2006, National Health Plan for 2006-2008. As part of the "protection of health in the early stages of life, childhood and adolescence», in representing the situation of disabled people for whom it is required a strong commitment to health care and social support for the family and the school, the Plan states that it is often necessary integration of skills across multiple disciplines that it must be ensured through the development of integrated models of interventions.

- Law 27th December 2006, no. 296, Provisions for the preparation of the annual and multi-annual State (Finance Act 2007). Article 1, paragraph 630, "projects offer qualified educational to children from twenty-four thirty-six months of age, including through the implementation of initiatives experimentations based on quality pedagogical flexibility, compliance with characteristics of the specific age group»; paragraph 1259, «basic level of benefits and the criteria and procedures on the basis of Regions delivering an extraordinary plan of action for the spatial development of social and educational services, which contribute to the nursery».

- Law 3rd March 2009, no. 18, Ratification and implementation of the UN Convention on the rights of persons with disabilities, with the optional proto- 
col, signed in New York on 13 December 2006 and the establishment of the National Observatory on the status of persons with disabilities.

- Presidential Decree, 20th March, 2009, no. 89, Revision of the didactic, organisational and structural system in infant school and the first cycle of instruction in accordance with Article 64, comma 4, of the Legislative Decree, 25th June 2008, no. 112, converted, with modifications, by the Law of 6th August 2008, no. 133.

- Regulations contained in National Recommendations for the curriculum of infant school and the first cycle of education, according to Article 1, comma 4, of the Presidential Decree, 20th March 2009, no. 89.

- Law 30th July 2010, no. 122, Conversion into law, with amendments, of Decree-Law 31st May 2010, no. 78, Urgent measures for financial stabilization and economic competitiveness. In particular, Article 10, paragraph 5, relates to the use of international classifications of WHO in the minutes of establishing the existence of a handicap to the formulation of the Individualized Education Plan (IEP).

- Law no. 107/2015, The Good School: The reform of the national system of education and training.

MIUR (Ministry of Education, Universities and Research) - Documents and Ministerial circulars:

- Ministerial Circular 5th September 1975, no. 235, The enrolment of handicapped children in nursery school.

- Ministerial Circular 8th August 1975, no. 227, Interventions in favour of handicappated pupils.

- Ministerial Decree 10th April 2008, no. 37, Criteria Spring Sections.

- Guidelines for the scholastic integration of pupils with disabilities, 2009.

- Guidelines: The participation of parents and educational co-responsibility, 2012.

- Ministerial Decree no. 254/2012, Indicazioni nazionali per il curricolo della scuola dell'infanzia e del primo ciclo d'istruzione / National recommendations for the infant school curriculum and the first educational cycle, Gazzetta Ufficiale / Official Gazette no. 30, 5th February 2013.

- Ministerial Directive 27/12/2012, Strumenti di intervento per alunni con Bisogni Educativi Speciali e organizzazione territoriale per l'inclusione / Courses of action for pupils with Special Educational Needs and organization for their national integration.

- Ministerial Circular 6th March 2013, no. 8, Strumenti di intervento per alunni con Bisogni Educativi Speciali / Courses of action for pupils with Special Educational Needs. School year 2013-2014. Clarifications.

- Ministerial Circular 26th August 2013, no. 22, Starting measures to complete National Recommendations, 2012. First attainments and deadlines. 
- Ministerial Note 27.06.2013, Piano Annuale per l'inclusività / Annual Plan for integration.

- Directive 27th December 2012 and Ministerial Note 22nd November 2013, Strumenti di intervento per alunni con Bisogni Educativi Speciali I Courses of action for pupils with Special Educational Needs. School year 20132014. Clarifications.

Agreements:

- Joint Conference State-Regions and local Authorities, 14th June 2007, Agreement between the Minister for Education, the Minister of Family Policies, the Minister of Social Solidarity, regions, provinces, municipalities and mountain communities, for the promotion of a training integrative and experimental for children aged two to three years.

- State-Regions Conference, 20th March 2008, Agreement between the government, the regions and the autonomous provinces of Trento and Bolzano, the provinces, the town councils and other small grouped communities concerning the modality and criteria for scholastic acceptance and responsibility for the handicapped pupil.

- Joint Conference State-Regions and local Authorities, 7th October 2010, Framework agreement for the realization of an offer of educational services for the benefit of children aged two to three years to improve the connections between nursery and kindergarten and contribute to the development of territorial socio-educational services 0-6 years. Agreement pursuant to Article 9, paragraph 2, letter c) of Legislative Decree 28 August 1997, no. 281.

- MIUR - Ministry of Health, 12th July 2012, Memorandum of understanding to safeguard handicapped pupils and students rights to health and study.

Initiatives for national and international training and experimentation:

- MIUR, National training plan for the integration of handicapped pupils, "I CARE: Learning, communicating, acting in an educational network", Academic years 2007/2008 and 2008/2009.

- MIUR - Presidency of the Council of Ministers, New technologies and disability, 2005-2013.

- MIUR, ICF project. From the ICF model by WHO planning for inclusion, 2010-2013.

- European Commission (2011). Early childhood education and care: Providing all our children with the best start for the world of tomorrow (Vol. 17/2/2011), Brussels.

- European Recommendation 112/2013 (20 February 2013), Investing in children for breaking the cycle of social disadvantage. 
Data and informations:

- Ministry of Education, The integration of handicapped pupils in kindergarten and compulsory schools, Rome, 1980.

- MIUR, Directorate General Ordinances school and school autonomy, National Joint Coordination Group Spring Sections, Spring Monitoring Sections 2010-2011.

- MIUR, Directorate General for Study, Statistics and for Information Systems - Statistics Service, September, 2013, 2014.

\section{BIBLIOGRAPHY}

Associazione Treellle, Fondazione Agnelli, \& Caritas (2011). Gli alunni con disabilità nella scuola italiana. Bilancio e prospettive. Trento: Erickson.

Baldacci, M. (2006). Ripensare il curricolo. Roma: Carocci.

Bertolini, P. (1992). La qualità della vita infantile: che fare? Firenze: La Nuova Italia.

Callari Galli, M. (1993). Antropologia e processi educativi. Firenze: La Nuova Italia.

Cancrini, L. (1974). Bambini «diversi» a scuola. Torino: Boringhieri.

Canevaro, A. (1996). Quel bambino là... Scuola dell'infanzia, handicap e integrazione. Firenze: La Nuova Italia.

Canevaro, A. (a cura di). (2007). Lintegrazione scolastica degli alunni con disabilità. Trent'anni di inclusione nella scuola italiana. Trento: Erickson.

Chiappetta Cajola, L. (1999). Handicap e valutazione. La funzione di controllo e di regolazione nel processo formativo degli allievi disabili. Roma: Anicia.

Chiappetta Cajola, L. (2007). L'impiego funzionale degli strumenti di integrazione scolastica. In A. Canevaro (a cura di), L'integrazione scolastica degli alunni con disabilità. Trentanni di inclusione nella scuola italiana (pp. 221-248). Trento: Erickson.

Chiappetta Cajola, L. (2008). Coordinate pedagogiche per l'infanzia (0-5). In A. M. Favorini (a cura di), Educare alla Speranza. Itinerari pedagogici e didattici speciali. Milano: FrancoAngeli.

Chiappetta, Cajola, L. (2012a). Educare al benessere: la progettualità pedagogica. In A. M. Favorini, Spiritualità, benessere e qualità della vita. Percorsi di formazione per un nuovo umanesimo (pp. 100-121). Milano: FrancoAngeli.

Chiappetta, Cajola, L. (2012b). Didattica del gioco e integrazione. Progettare con l'ICF. Roma: Carocci.

Dixon-Krauss, L. (2000). Vygotskij nella classe. Potenziale di sviluppo e mediazione didattica. Trento: Erickson. 
Falcinelli, F., \& Alteri, P. (a cura di). (2005). Le educatrici dei servizi per la prima infanzia. Contributi di ricerca e riflessione su una professionalità in mutamento. Bergamo: Junior.

Frabboni, F. (1975). La scuola materna. Firenze: La Nuova Italia.

Ianes, D. (2014). L'evoluzione dellinsegnante di sostegno. Verso una didattica inclusiva. Trento: Erickson.

Macchietti, S. S. (a cura di). (2005). Il Bambino e l'educazione. Per una ricomprensione della pedagogia dell'infanzia. Roma: Euroma.

Mantovani, S. (2002). I servizi educativi per la prima infanzia. Firenze: Istituto degli Innocenti.

Medeghini, R., D’Alessio, G., Marra, A., \& Valtellina, E. (2013). Disability Studies, emancipazione, inclusione scolastica e sociale, cittadinanza. Trento: Erickson.

MIUR (1993). Gli Orientamenti per la scuola materna. Firenze: Le Monnier, Annali della Pubblica Istruzione.

Montessori, M. (1938). Il segreto dellinfanzia. Milano: Garzanti.

Musatti, T., \& Mayer, S. (a cura di). (2003). Il coordinamento dei servizi per l'infanzia. Una funzione emergente in Italia e in Europa. Bergamo: Junior.

Neri, S. (1980). La metodologia della scuola dell'infanzia. In G. Sciacovelli (a cura di), Guida al tirocinio della scuola materna. Milano: Fabbri.

OECD (2012). Equity and quality in education - Supporting disadvantaged students and schools.

Onida, V. (2006-2009). Costituzione, valori sociali comuni, scuola. http://www. rivistaaic.it

Pavone, M. (2010). Dall'esclusione all'inclusione. Lo sguardo della pedagogia sociale. Milano: Mondadori.

Pontecorvo, C. (1990). Una scuola per i bambini. Firenze: La Nuova Italia.

Santosuosso, F. (1993). Essenziali valori sociali e tutela costituzionale. Giur. It. IV.

Trisciuzzi, L., \& Cambi, F. (1989). L'infanzia nella società moderna. Roma: Editori Riuniti.

UNESCO (2008). Inclusive education: The way of the future. http://www.ibe.unesco. org/en/ice

UNESCO (2005). Guidelines for inclusion: Ensuring access to education for all. Paris: UNESCO.

Vygotskij, L. S. (1974). Storia dello sviluppo delle funzioni psichiche superiori. Firenze: Giunti.

Zanelli, P. (1986). Uno sfondo per integrare. Bologna: Cappelli. 


\section{RiassunTO}

La scelta della piena integrazione che l'Italia ha intrapreso da molti decenni è particolarmente apprezzata a livello internazionale. È una scelta irreversibile che richiede continui miglioramenti da apportare in un contesto scolastico che comprende una grande diversità di soggetti. Durante l'infanzia, infatti, la scuola italiana accoglie, promuove e arricchisce l'esperienza di ogni bambino per promuoverne lo sviluppo; le attività didattiche offrono opportunità di crescita in un contesto orientato al benessere, alla consapevolezza e verso il progressivo sviluppo di specifiche competenze. In ogni attività educativa, la scuola organizza la propria azione in linea con i principi dell'inclusione piena della persona. Questo articolo espone come l'inclusione scolastica è realizzata in Italia per i bambini con disabilità dai 3 ai 6 anni. Esso descrive la situazione, sia quantitativamente che qualitativamente, secondo il quadro offerto dai principi fondamentali sanciti a livello internazionale e in base alla Costituzione italiana, a leggi, documenti, informazioni e a dati provenienti da fonti autorevoli. Lo studio, presentato dall'autrice nel «Deutschen Gesellschaft für Erziehungswissenschaft Kongress» (Humboldt Universität, Berlino, 9-12 marzo 2014), è nato nell'ambito di una ricerca europea a carattere comparativo che ha coinvolto Italia, Inghilterra, Germania e Slovenia al fine di analizzare come l'inclusione scolastica è organizzata in Europa, in particolare, in relazione alle risorse del sistema di istruzione, alla formazione degli insegnanti e alle aspettative sociali rispetto al ruolo della scuola dell'infanzia.

Parole chiave: Disabilità, Formazione degli insegnanti, Inclusione, Scuola italiana dell'infanzia, Sostegno.

How to cite this Paper: Chiappetta Cajola, L. (2015). Conditions, standards and practices of inclusion for children with disabilities in Italian infant school [Modalità, standard e pratiche di inclusione per i bambini con disabilità nella scuola dell'infanzia italiana]. Journal of Educational, Cultural and Psychological Studies, 12, 169-215. doi: 10.7358/ecps-2015-012-chia 